University of Konstanz

Department of Economics

\title{
Unemployment, Human Capital Depreciation and Pension Benefits: An Empirical Evaluation of German Data
}

Niklas Potrafke

Working Paper Series 2011-05 


\title{
Unemployment, human capital depreciation and pension benefits: an empirical evaluation of German data
}

\author{
Niklas Potrafke* \\ University of Konstanz
}

This version: April 25, 2011

\begin{abstract}
This paper investigates empirically how unemployment-induced employment-breaks at different career stages influence pension benefits. The analysis is based on German data. I distinguish four different career phases and investigate to what extent the prevailing social security policy compensated for earning losses. The results suggest that (1) losses in pension benefits were the greatest if unemployment occurred in the middle of a career (between 31 50); (2) social security policies have had a mitigating effect on losses in pension benefits. These findings indicate that institutions have a decided influence on how career patterns translate into pension benefits.
\end{abstract}

Keywords: employment histories, career interruptions, pension benefits, social security policy, human capital depreciation, institutions

JEL Classification: J26, J24, H55, I38

\footnotetext{
* University of Konstanz, Department of Economics, Box 138, D-78457 Konstanz, Germany, Phone: + 497531 88 2137, Fax: + 49753188 3130. Email: niklas.potrafke@uni-konstanz.de I thank Friedrich Breyer, Courtney Coile, Winfried Pohlmeier, Michael Stegmann, Heinrich Ursprung, Selver Derya Uysal and two anonymous referees for helpful comments and suggestions. I started to work on this project when I was a visting research fellow at the German Economic Institute (DIW) in 2006/2007. I am indebted to Viktor Steiner, Johannes Geyer and Ronny Freier.
} 


\section{Introduction}

Individual employment histories determine the level of pensions people receive when they reach retirment age. The higher a worker's individual earnings and the more continuous his career, the higher the pension benefits will be if contributions are closely linked to benefits. In other words, employment-breaks due to, for example, unemployment will reduce future earnings and pension benefits. These losses in pension benefits can be expected to depend on when the employment-break occurs because the on-the-job accumulation of human capital varies over the employment career. Social security policies are, of course, explicitly designed to mitigate unforseen losses but they can only insure against income losses not against foregone accumulation of human capital.

Information on the influence of employment-breaks on pension benefits is important because social security policies have significant distributional effects. In the course of demographic change intra- and intergenerational redistribution effects of public pension systems often necessitate the old-age coverage to be redefined. ${ }^{1}$ Some scholars have indeed investigated the influence of employment-breaks on pension benefits in Germany (e.g., Wunder 2005) and have shown that unemployment-induced employment-breaks give rise to negative long-run effects. I am however not aware of any study that analyzes the influence of employment-breaks on pension benefits giving due consideration to the career-state at which the break occurred. Mitigating social security policy measures have also not been taken into account in the relevant literature so far. Unemployment-induced losses in pension benefits may however not only differ because of foregone accumulation of human capital but also because of to what extent the prevailing social security policy compenstated for earning losses. In fact, employment offices provide contributions to the pension insurance during unemployment-induced employment-breaks. In Germany, the amount of contributions the

\footnotetext{
${ }^{1}$ See, for example, Fehr and Habermann (2006), Breyer and Kifmann (2002), Börsch-Supan et al. (2008) and Fehr et al. (2011) on reforms of the German pension system. Various studies investigate income redistribution in public pension systems (see, for example, Hupfeld 2009 and 2011 for Germany).
} 
Federal Employment Office made differed over time; for example, unemployment-induced employment-breaks were credited more generously after $1978 .^{2}$ It is the objective of this study to analyze the points of times at which unemployment hits the worker and the role of social security policies in this context.

In this paper, I use the biographical dataset from the German Pension Insurance (SUF VVL 2004) in order to investigate empirically (1) how unemployment-induced employmentbreaks influence Earning Points of West German men giving due consideration to the careerstate at which the break occurred and (2) how social security policy mitigated the resulting pension losses. The dataset contains detailed information on pension benefits and individual employment histories. The SUF VVL 2004 is the first dataset covering both of these sets of information. ${ }^{3}$ My study takes advantage of the interaction between individual employmentbreaks and the social security policy which was pursued at the time of this break. The results suggest that (1) losses in pension benefits were the greatest if unemployment occurred in the middle of a career (between 31 and 50); (2) social security policies have had a mitigating effect on losses in pension benefits. These findings indicate that institutions have a decided influence on how career patterns translate into pension benefits.

The paper is organized as follows. Section 2 discusses theoretical aspects and related empirical literature on the influence of employment-breaks on wages and pension benefits. Section 3 portrays the German pension rules. Section 4 presents the data and specifies the empirical model. Section 5 reports and discusses the estimation results. Section 6 concludes.

\footnotetext{
${ }^{2}$ The generosity of the social securtity system and unemployment insurance may also influence retirement transitions. See, for example, Coile and Levine (2007) for a study on the United States.

${ }^{3}$ In the meantime the dataset "Versichertenkontenstichprobe 2005/2006" has been published that contains similar information.
} 


\section{The influence of employment-breaks on wages and pension benefits:}

\section{theoretical background and related empirical evidence}

\subsection{Theoertical background}

The differences in pension benefits due to personal events in the individual life cycle are determined by several factors. The theory of human capital accumulation provides the most useful theoretical background. Human capital is a means of production, and additional investment (via education, training etc.) will yield additional output (Becker 1964). The lifecycle growth of earnings reflects the rate of accumulation of personal investments. ${ }^{4}$ In total, wages increase over the working life.

Human capital depreciation due to career interruptions is likely to cause lower earnings (e.g., Mincer and Polachek 1974): according to the theory of human capital depreciation, lengthy employment-breaks decrease wages at the probability of re-entry to the labor market because individuals were unable to keep up with technological progress which, in turn may be demotivating. As a result of human capital depreciation, post-interruption wages are initially quite low but increase rapidly when the individual continues working. Gradually, the human capital that depreciated during the employment-break is restored. Mincer and Ofek (1982) describe the restoration effect that alleviates income losses: as can be expected, its positive impact depends on the particular phase of life under consideration because skills, knowledge, and experience change over the career. Career interruptions are therefore valued differently on the labor market, which in turn affects individual income differently. While the restoration effect appears to be stronger in the early and middle phases of life than in the later employment phase of life, the direct losses of human capital depreciation appear greater in the late employment phase of life. For this reason the

\footnotetext{
${ }^{4}$ Mincer's (1974) famous "human capital earnings function" relates the natural logarithm of income to the number of years of education and experience. Mincer (1993) portrays his previous studies on human capital.
} 
interaction between the negative direct human capital depreciation effect and the positive restoration effect remains an open empirical question.

Human capital depreciation and earning losses concern pension benefits directly because they interact with earnings and thereby with individual qualifications during the employment period. ${ }^{5}$ Contributions to the social security system and benefits are closely linked in countries with a so called Bismarckian social security system such as in Germany. In section 3, I portray the German pension rules in detail.

When a worker experiences an employment break, three effects influence her/his pension benefits. First, the worker experiences a period of lost wages and lost direct contributions to the social security system. To be sure, the social security system may compensate the missing contributions (in part or in full). This is however a matter of social security policy. Second, the worker may suffer a loss of experience and human capital which may reduce her/his wages at the subsequent job(s). Third, the worker may respond to the lost wages by working more hours or retire later. I will first investigate how these combined effects influence pension benefits and then disentangle these combined effects from mitigating social policy effects.

\subsection{Empirical evidence for Germany}

Empirical studies suggest that employment-breaks cause income losses in Germany. Licht and Steiner (1992) use data from the German Socio-Economic Panel (GSOEP) in the period 19841989 and find persistent losses in income directly after an employment-break, as well as an indirect effect due to the lack of human capital accumulation. Income increases, however, after reemployment (restoration effect), which somewhat compensates for the aforementioned negative effects. Using a dataset from the German social security system (IAB employment sample), Beblo and Wolf (2002) examine the wage effects of different types of career

\footnotetext{
${ }^{5}$ On retirement savings decisions over the life-cycle see, for example, Lachance (2011).
} 
interruptions. The results suggest that for both men and women, early job experiences contribute less to current income than recent experiences gained from employment. ${ }^{6}$

Previous research has also shown that unemployment-induced employement-breaks decrease pension benefits of West German men: Wunder (2005) analyzes the influence of unemployment on pension benefits for different age cohorts, but does not give consideration to the career-state at which the break occurred. He uses data from the GSOEP. His results show that, especially for short employment histories, the effect of the depreciation in human capital is stronger than the negative income effect of lower contributions to the social security system. Unemployment of workers belonging to younger cohorts tends to have a stronger negative influence on pension benefits than unemployment of workers belonging to older cohorts. This research thus indicates that the point of time at which unemployment hits the worker influences pension benefits. Yet previous research did not explicitly investigate the influence of the point of time at which unemployment hits the worker on pension benefits in Germany, which I will do in this paper. ${ }^{7}$ The first hypothesis to be investigated is:

H1: unemployment-induced employment-breaks in the early and middle phase of a career have a stronger negative influence on pension benefits than unemployment-induced employment-breaks in the last phase of a career.

\footnotetext{
${ }^{6}$ Kunze (2002) uses IAB data as well, and finds that the influence of not working depends on the type of interruption. A related strand of literature investigates the influence of employment breaks because of parental leave on wages and employment behavior. See, for example, Beblo et al. (2009), Görlich and De Grip (2009), Geyer and Steiner (2007).

${ }^{7}$ The association between pension benefits and individual employment histories in Germany was first examined in a survey study called AVID '96 (Altersvorsorge in Deutschland). See Schatz et al. (2002) for a more detailed description of the AVID'96 and Frommert et al. (2008) on the updated AVID' 2005. In contrast to the present study, the AVID 96 focused on pension benefits in monetary units. For descriptive evaluations employing the AVID 96 see, for example, Kortmann and Schatz (1999), Roth (2000), Bieber and Stegmann (2000), Hauschild (2002), Steiner (2003), Himmelreicher and Frommert (2006).
} 
The theory of human capital accumulation and the related empirical studies do not consider the institutional framework. ${ }^{8}$ In fact, labor market policies such as training programs or unemployment insurance are designed to mitigate human capital depreciation and earning losses when individuals are unemployed. Social security policies that provide benefits during career interruptions are designed to compenstate for missing contributions when individuals have reached old-age. In Germany, for example, the government provides benefits during career interruptions due to unemployment, parental leave, studying or military service. Consequently, studies examining the effects of human capital depreciation on pension benefits should take into account social security policies. The second hypothesis to be investigated is:

H2: the more generous the government's benefits to compensate the losses due to unemployment-induced employment breaks, the smaller are the negative direct earning losses and human capital depreciation effects on pension benefits.

\section{German pension rules}

Social security policy is designed to mitigate losses due to employment-breaks. How unemployment influences pension benefits is thus also a matter of institutional rules. In the German public pension system, pensions of individual $i$ in month $t$ are determined by the following formula ${ }^{9}$ :

\footnotetext{
${ }^{8}$ Geyer and Steiner (2010) investigate the influence of changing employment patterns and pension reforms on the future level of public pensions across birth cohorts in Germany. In a similar vein, Bucheli et al. (2010) provide evidence for Uruguay.

${ }^{9}$ Some scholars criticize this formula. The linkage between individual contributions and benefits, for example, appears to neglect the fact that life expectancy is positively correlated with income (Breyer and Kifmann 2004). Breyer and Hupfeld (2009) have proposed a new concept of "distributive neutrality" that considers incomegroup-specific differences in life-expectancy.
} 
Pension $_{\mathrm{it}}=$ Earning Points $_{\mathrm{i}} \times$ Pension Type Factor $_{\mathrm{i}} \times$ Entry Factor $_{\mathrm{i}} \times$ Current Pension Value $_{\mathrm{t}}$

The Current Pension Value (Aktueller Rentenwert) is fixed for all pensioners in (former) East and West-Germany (since July 1, 2009 the Current Pension Value is 27.20 Euro in former West Germany and 24.13 Euro in former East Germany) and relates to the product of the net replacement rate and the so-called adjusted gross earnings. By taking into account demographic changes the Current Pension Value is an important link between intergenerational redisbribution and demography.

The Entry Factor is equal to one if the age at retirement equals the statuary retirement age and is lower for early retirement. The Pension Type Factor describes the pension type such as old-age pensions, disability pensions or survivor pensions and only differs from one for survivor-pensions and some disability pensions.

The Earning Points (Entgeltpunkte) correspond to the ratio of a worker's contributable income to the mean contributable income of all workers of the same year. For each pensioner cohort, the Earning Points link the individual contributions to the benefits (TeilhabeÄquivalenz). The Earning Points thus define how general income changes over time are distributed in an individual generation in the German public pension system. Moreover, employment-breaks due, for example, to unemployment are also accounted for in the Earning Points. How unemployment has been accounted for depends on the policy which was effective at the time of the unemployment spell. See Lühning (2006), for example, for an encompassing portrait of the changes in the German social security system's benefit legislation that have been implemented between 1957 and 2004.

Until 1978, the Federal Employment Office did not make contributions to the social security system in case of career interruptions due to unemployment. Phases of unemployment were credited only in the final assessment of the entire (potential) working life (period from the age of 17 to the start of the pension). From 1979 to 1991, the Federal 
Employment Office made contributions to the social security system in case of career interruptions due to unemployment. The social security policy designed to mitigate losses due to unemployment became more generous after 1978 (especially for low-income workers who clearly risked unemployment because contributions were then also based on unemployment benefits and not only on past income). ${ }^{10}$ The year 1992 constituted a turning point: from then on, the Federal Employment Office made (compulsory) contributions to the social security system in almost all cases. ${ }^{11}$

\section{Data and empirical model}

\subsection{The data set - SUF VVL 2004}

The data analyzed is the Scientific Use File (SUF) "FDZ-Biografiedatensatz für die Biografiedaten zu Vollendeten Versichertenleben (VVL) 2004”, provided by the German Pension Insurance. The VVL 2004 is a 20\% sample of all retirement entries in 2004 aged 30 to 65 . The SUF represents a $25 \%$ subsample out of the $20 \%$ sample of all retirement entries in 2004 aged 30 to 65 and only contains cases of new entrants and no transmutations. The data refers to pensions deriving from own contributions and therefore do not include widow's pensions etc. The SUF is unfortunately not representative for the entire pensioner population in Germany in 2004, as it only covers the inflow and not the stock. ${ }^{12}$

In comparison to the GSOEP the SUF does however not suffer from panel mortality. The GSOEP provides survey data, whereas the SUF contains administrative data. In

\footnotetext{
${ }^{10}$ To be sure, individuals that became only temporarily unemployed for some months after leaving university and then never became unemployed the new statute was not favorable. These individuals are execptions however.

${ }^{11}$ This categorization somewhat simplifies the amendments. From July 1978 to the end of 1982, the Federal Employment Office made contributions to the public pension scheme on the basis of gross labor income, which constituted the claim for unemployment benefits. From 1983 to the end of 1991, the Federal Employment Office made contributions on the basis of the unemployment benefits granted. There was an interim arrangement from 1992 to 1997, under which periods of unemployment were also considered in the final assessment. From 1998 on, contributions were made on the basis of $80 \%$ of gross labor income, which constituted the claim for unemployment benefits.

${ }^{12}$ See Stegmann (2006a), for example, for an encompassing portrait of the preparation and the set-up of this dataset and Stegmann (2006b) and Fachinger and Himmelreicher (2006) for a comparison of the properties of the SUF VVL 2004 with other already existing databases.
} 
comparison to the Institute for Employment Research (IAB) employment sample which has so far been the most comprehensive data set covering biographical information, the SUF contains wide-ranging information about the individual employment histories. The IAB employment sample only goes back to 1975, whereas the SUF 2004 goes back to 1953.

The SUF reports individual facts such as pension amounts, pension types, and above all the Earning Points that measure the individual claim to pension benefits. The Earning Points allow estimating the relative earnings position of individuals. This is a significant advantage compared to other datasets that refer, for example, to the monthly pension amount which is dependent on the real wage. I will use the logarithm of the Earning Points as the dependent variable in my empirical model (see Section 4.2).

The SUF contains information about the individual social earning situation over time, including characteristics such as unemployment. The observation period covers 624 monthsfrom January 1953 to December 2004. The oldest individuals included are born in 1939 and the youngest ones in 1974. As I will focus on the working period up to the age of 56, I only include individuals born in the interval between 1939 and 1947. Hence in 2004, the youngest individuals were 57 and the oldest 65 years old. ${ }^{13}$

The dataset also contains information on other socio-demographic characteristics such as marital status, citizenship, and education. ${ }^{14}$ The empirical model can therefore fall back on variables which are all taken from the SUF.

\footnotetext{
${ }^{13}$ The sample contains some missings - also within individual careers. The interpretation of the missings is significant because a missing value means that the respective month was not relevant from the perspective of social security law, but it does not affect pension benefits in any way. Hence one can circumscribe the periods for which information is available from all the other states. For example, the only relevant periods of unemployment (from a social security law perspective) are the ones coded as unemployed. The relevant periods of unemployment can be distinguished from all the other states. Using a variable on the social-economic situation ensures that there is no overlapping of potentially parallel employment breaks relevant from a social security law perspective. However, the variable on the social-economic situation is coded hierarchically. Consequently, periods of parental leave that occurred parallel to full-time employment are not considered: in this case, full-time employment takes priority.

${ }^{14}$ The classification of the education status is based on a mechanical reporting system which employers provide to the German Pension Insurance (Tätigkeitsschlüssel nach DEÜV). The pensioners report however their sociodemographic characteristics such as sex, marital status and nationality themselves. Further information on, for example, personal traits are not available which in turn are also likely to influence employment duration (e.g. Uysal and Pohlmeier 2011).
} 
The analysis included pensioners living in West Germany (Berlin is also excluded) because East Germans' careers differed due to the economic and political system in the former German Democratic Republic. The dataset also allows identifying individuals who lived in the western part of Germany in 2004 but actually have spent their working life in the East. I only include individuals in the sample that spent their entire working lifes in West Germany and also restrict my conclusions to persons covered by the compulsory German social security system. ${ }^{15}$ Following Wunder (2005), I focus on men.

Table 1 summarizes the distribution of the Earning Points in relation to the period of registry in the German pension insurance system. Disregarding the period of coverage men's Earning Points on average add up to 52.13. The sum of the Earning Points, however, does not increase strictly with longer periods of coverage. Men registered with the German pension insurance system for at least 40 years received 57.20 Earning Points on average. The numbers presented refer to the final sub-samples. Table 1 also shows that the large majority of the individuals in the sample were registered between 45 and 49 years. In the base-line specification I will consider an affiliation time of at least 25 years. For robustness checks I will compare the results with a longer affiliation of at least 40 years. These two benchmarks take into account the respective sample sizes and distributional properties.

\subsection{The empirical model}

\subsubsection{Estimation approach}

I investiage hypothesis 1 first in separation from hypothesis 2 and use the following linear regression model:

\footnotetext{
${ }^{15}$ As the dataset contains information on the months accounted for in the social security system such as employment time and different periods of allowances (e.g., periods of self-employment are not taken into account), I can distinguish between different specifications in relation to the period of registry in the German pension insurance system.
} 
$\log$ Earning Point $_{\mathrm{i}}=\sum_{\mathrm{j}} \alpha_{\mathrm{j}}$ Employment-Breaks $_{\mathrm{ij}}+\sum_{\mathrm{m}} \delta_{\mathrm{m}} \mathrm{X}_{\mathrm{im}}+\mathrm{u}_{\mathrm{i}}$

with $\mathrm{j}=1, \ldots, 4 ; \mathrm{m}=1, \ldots, 8$

The dependent variable "log Earning Points" describes the logarithm of the Earning Points of individual i. I take the logarithm of the Earning Points in order to interpret the influence of the independent variables on the Earning Points as changes in percentages. "EmploymentBreaks $_{\mathrm{ij}}$ " models the career interruptions. In the next paragraph I explain their coding in detail. The term " $\mathrm{X}_{\mathrm{im}}$ " contains a constant term and eight explanatory dummy variables for control purposes: family status (married), citizenship (german) and education, where I distinguish between Lower School (Hauptschule), Secondary School (Realschule), High School Diploma (Abitur) with professional training, High School Diploma (Abitur) without professional training, Advanced Technical College Degree, University Degree and unknown education. ${ }^{16}$ To avoid pefect collinearity between the education dummies, one of the education dummies must function as the reference category (here unknown education). The estimated effects of the other education dummies then must be interpreted as deviations from the reference category.

The linear regression model that investigates hypothesis 1 together with hypothesis 2 has the following form:

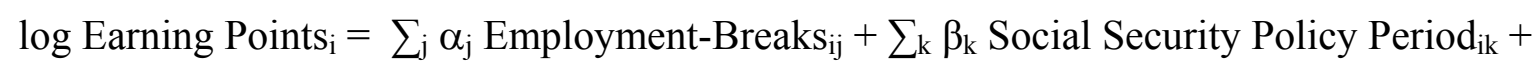
$\sum_{1} \gamma_{1}$ Employment-Breaks $_{\mathrm{ij}} *$ Social Security Policy Period ${ }_{\mathrm{ik}}+\sum_{\mathrm{m}} \delta_{\mathrm{m}} \mathrm{X}_{\mathrm{im}}+\mathrm{u}_{\mathrm{i}}$ with $\mathrm{j}=1, \ldots, 4 ; \mathrm{k}=1 ; \ldots ; 3 ; \mathrm{l}=1,2 ; \mathrm{m}=1, \ldots, 8$

\footnotetext{
${ }^{16}$ The characteristic „unknown education“ is not a missing value. It is likely that the education of these individuals is quite low. In some cases, however, education might just be unknown because employers did not ask for this information.
} 
The model described in equation (2) is similar to the model in equation (1). I now also include the "Social Security Policy Period ${ }_{\mathrm{ik}}$ " dummy variables that control for revisions of a statute. I illustrate my categorization and the respective modelling below (following the main amendments as described in Section 3). "Employment-Break $\mathrm{i}_{\mathrm{ij}}$ * Social Security Policy Period $_{\mathrm{ik}}$ " describes interaction terms. I consider these interaction terms because the number of Earning Points is likely to depend on the policy which prevailed when the individual was unemployed. I estimate the models with ordinary least squares (OLS) with robust standard errors.

\subsubsection{Employment-break variables}

The choice of the employment-break variables is similar to the work history model first introduced by Light and Ureta (1995) and extended, e.g., by Beblo und Wolf (2002). First I distinguish between four different phases during the entire employment period with respect to the individuals' career ages: the earliest employment phase extends from 21 to 30; the next two intervals extend from 31 to 40 and 41 to 50 . The last phase extends from 51 to 60 for the age cohorts 1939 to 1943 , from 51 to 59 for the age cohort 1944, from 51 to 58 for the age cohort 1945, from 51 to 57 for the age cohort 1946 and from 51 to 56 for the age cohort 1947. For simplicity I refer to the last phase as the phase of life 51-60. I compute phase-specific unemployment shares, i.e., I sum up the individual number of months an individual has been unemployed in the respective phase and relate this number to 120 months in the first three phases of life, and 120,108, 96, 84 and 72 months respectively in the last earning phase. For robustness checks I will also consider only pensioners who did not retire before the age 60 .

Table 2 shows the means of the employment-break variables conditional on when the career interruption occurred, their numerical frequency of the breaks and the means of the Earning Points. As expected, unemployed men received fewer Earning Points than employed men. However, there are differences between the individual employment phases of life. The 
difference between Earning Points is highest in the phase of life 41-50 (45.44 to 56.12). It is lower in the late phase of life 51-60 (51.61 to 55.54). Differences in mean Earning Points among those employed versus unemployed could reflect a selection problem. I therefore checked the distribution of the oberservable socio-demographic characteristics such as marital status, citizenship, and education of employed versus unemployed men. T-tests on sample means show that men who were unemployed had somewhat lower education and were somewhat less likely to be married. I control for education and marital status in the econometric model. To be sure, I acknowledge that I cannot completely eliminate the concern that the two groups might differ on unobservables.

The number of unemployed men was much larger in the last phase of life (997) than in the 41-50 (608), 31-40 (594) and 21-30 phases of life (283). The duration of unemployment was much larger in the last employment phase of life (the mean share of unemployment in the phase of life 51-60 is 0.21). Correlation between the individual phases of unemployment is very low. This means, for example, that unemployment in the middle phases of life did not make unemployment in the last phase of life more likely. The numbers presented refer to periods of at least 25 years. I normalize (mean zero, variance one) the unemployment share variables in order to consider the different distributional properties of the variables and to be able to compare the numerical meaning of the coefficients in the econometric model directly.

\subsubsection{Policy period variables}

I distinguish between policy sub-periods defined by the main amendments as described in Section 3. The respective dummy variables take on the value of one when an individual's career was interrupted in this period and zero otherwise. I consider three different policy subperiods regarding the amendments of unemployment: pre-1978, 1979-1991, and post-1992.

The years, in which policy changes became effective, were coded accordingly. For example, when a law changed in May (first half of the year), I consider the entire year as 
affected by this statute. Changes in the second half of the year are taken into account the following year. Table 3 shows descriptive statistics of the variables included.

\subsubsection{Interaction Terms}

I control for the effect that employment-breaks occurred in different policy periods. The first amendment dealing with unemployment occurred in 1978, and hence, all the individuals born between 1939 and 1947 were affected by the first policy period in their early phase of life (age 21-30). Therefore, the interaction term between the first phase of working life and the dummy referring to the first policy period is not different from the employment-break variable itself. In contrast, there are differences for the middle phases of life 31-40 and 41-50. Older individuals, e.g., those born in 1939, experienced the first years of their phase of life 31-40 under the first policy regime up to 1978. But younger individuals, e.g., those born in 1947, experienced nearly their entire phase of life $31-40$ in the second policy period 19791991. Hence I control for the interaction of unemployment in the phase of life 31-40 with the period after the first amendment of 1978. I expect a positive influence of this interaction term on the log Earning Points because social polices became more generous after 1978. The setting is similar for the phase of life 41-50. Individuals, e.g. those born in 1939, spent their phase of life 41-50 in the policy period 1979-1991. In contrast, younger pensioners, e.g., those born in 1947, experienced several years of their phase of life 41-50 after the last amendment of 1992. Therefore, I include the interaction term of unemployment in the phase of life 41-50 with the third policy period and again expect a posivite influence of this interaction term on the log Earning Points. All pensioners experienced their phase of life 51-60 after the last amendment of 1992. I thus cannot distinguhish between employment-break effects in the phase of life 51-60 for different policy periods. I normalize (mean zero, variance one) the unemployment share and the social policy variables before interacting. 


\section{Results}

\subsection{Basic results}

Table 4 reports the regression results when policy variables are not included. In columns (1) and (2) the control variables are excluded to show that the effects of the unemployment share variables are not influenced by the inclusion/exclusion of the control variables. The control variables in columns (3) and (4) display the expected signs. The dummy variable "family status (married)" is statistically significant at the 1\% level and indicates that Earning Points of married men were about $13 \%$ higher than Earning Points of unmarried men. The dummy variable "citizenship (German)" is statistically significant at the $1 \%$ level and indicates that Earning Points of German men were about 23\% higher than Earning Points of Non-German men. In columns (3) and (4), the education variables "Secondary School (Realschule)", "High School Diploma (Abitur) with professional training", "High School Diploma (Abitur) without professional training", "Advanced Technical College Degree”, "University Degree” are all statistically significant at the $1 \%$ level with the expected positive signs. They indicate that Earning Points were about $16 \%$ to $32 \%$ higher for pensioners with the different educational degrees compared to pensioners with unknown educational degree. The "Lower School (Hauptschule)" variable is statistically significant at the 5\% level in column (3) and at the $10 \%$ level in column (4) and has a negative sign. The estimates suggest that pensioners with a Lower School (Hauptschule) education had fewer Earning Points (about 4\% less) compared to pensioners with no educational degree. The reason may be that education at this quite low level does basically have no huge influence on job market opportunities and is similar to an unknown educational degree. The R-squared ranges from 0.07 in column (1) to 0.22 in column (4) which indicates a quite good explanatory power for a micro-econometric model.

The results reported in Table 4 clearly show that the point of time at which unemployment hits the worker influenced pension benefits. Being unemployed at any point during working life reduced Earning Points as expected. The variable for unemployment over 
the entire working life is statistically significant at the $1 \%$ level in columns (1) and (3). As the unemployment share has been normalized, the coefficient implies that a one-standarddeviation change in the unemployment share is associated with a $8.7 \%(6.7 \%)$ reduction in Earning Points. The results in columns (2) and (4) show that unemployment in the phases of life 31-40 and 41-50 had a greater negative influence on Earning Points than unemployment in the phases of life 21-30 and 51-60. A one-standard-deviation change in the unemployment share in the phase of life 21-30 reduced Earning Points by about 0.8\%, in the unemployment share in the phase of life $31-40$ by about $4 \%$, in the unemployment share in the phase of life $41-50$ by about $5.2 \%$, and in the unemployment share in the phase of life $51-60$ by about $2.3 \%{ }^{17}$ The coefficients of the unemployment share variable $21-30$ are statistically significant at the $10 \%$ level whereas the other unemployment share variables are statistically significant at the $1 \%$ level in columns (2) and (4). An F-Test that the unemployment share variables 2130, 31-40, 41-50 and 51-60 jointly lack statistical significance can be rejected at the 1\% level. F-Tests also show that the difference of the coefficients of the unemployment variable 21-30 and the other unemployment share variables and the difference the coefficients of the unemployment variable 51-60 and the other unemployment share variables is unequal to zero at the $1 \%$ level. The coefficients of the unemployment share variables $31-40$ and $41-50$ do however not turn out to be statistically different.

Table 5 reports the regression results when the unemployment share variables, the social policy variables and the interaction terms between the unemployment share variables and the social policy variables are included. The influence of the control variables hardly differs from the results in Table 4. The unemployment share variables (31-40, 41-50 and 5160) are again statistically significant at the $1 \%$ level.

\footnotetext{
${ }^{17}$ It is important to note that the effect of unemployment in the phases of life 31-40 and 41-50 is also larger in absolute terms than unemployment in the phases of life 21-30 and 51-60. In absolute terms, the effect of unemployment in the phases of life 31-40 and 41-50 is about two times larger than unemployment in the phase of life 21-30 and about four times larger than unemployment in the phase of life 51-60. Recall from Table 3 that the standard deviations of the unemployment share variables are larger at older ages.
} 
The social policy variable for the first period (till 1978) is statistically significant at the $1 \%$ level in column (1) and at the 5\% level in column (2) and has a negative sign. The social policy variable for the second period (1979-1991) is statistically significant at the $1 \%$ level in columns (1) and (2) and has a negative sign, whereas the social policy variable for the third period does not turn out to be statistically significant. It is important to remind that I only include two interaction terms because all pensioners experienced their phase of life 21-30 before the first amendment of 1978 and all pensioners experienced their phase of life 51-60 after the last amendment of 1992. The interaction term between the unemployment share variable for the phase of life $31-40$ and the social policy variable for the second period is statistically significant at the $10 \%$ level in column (1) and at the 5\% level in column (2) and has a positive sign. The interaction term between the unemployment share variable for the phase of life 41-50 and the social policy variable for the third period lacks statistical significance.

The marginal effects of the unemployment share variables have to be interpreted conditionally on the interaction with the social policy variables (see Friedrich 1982). In principle, there are two ways to evaluate the marginal effects. I follow Dreher and Gassebener (2007) and evaluate the marginal effects at the minimum and at the maximum of the interacted variable. Using this method one can distinguish between the influence of being unemployed in a particular phase of life when the German government implemented a particular social policy. If one chooses to evaluate the marginal effects at the average level of the social policy variables, the statistical significance of these average effects corresponds to the t-statistics of the unemployment share variable. Table 6 indicates that the marginal effects were statistically significant at the $1 \%$ and $5 \%$ level under different policy periods.

The marginal effects presented in Table 6 can be interpreted as follows: a onestandard-deviation change in the unemployment share in the phase of life 31-40 reduced Earning Points by about $4.8 \%$, when unemployment occurred in the social policy period 1 till 
1978 , but only by about $1.6 \%$ in the second social policy period after 1978 . A one-standarddeviation change in the unemployment share in the phase of life 41-50 reduced Earning Points by about 3.4\% when unemployment occurred in the social policy period 2 (1979-1991) but only by about $3.1 \%$ in the third social policy period after 1992 . Social policy therefore significantly mitigated the losses from unemployment after 1978. Only weak additional effects occurred in the third compared to the second social policy period.

\subsection{Robustness tests}

I have checked the robustness of the results in several ways. The sample included also pensioners that retired at the ages 56-59. Since the official retirement age has been 60 for several years (the de facto retirement age was lower however) I have excluded the individuals aged 56-59 because their working lifes might be different from the standard pensioners retiring at the ages 61-65. The results are very similar to the results presented in Tables 4 to 6 and inferences do not change.

The results in Tables 4 to 6 refer to a period of coverage of at least 25 years. I have also investigated coverage periods of at least 40 years. The estimated losses due to unemployment over the entire working period are somewhat smaller when coverage was at least 40 years: a one-standard-deviation change in the unemployment share over the entire working life reduced Earning Points by about $6 \%$ on average. The losses in the last employment phase of life 51-60 were also somewhat smaller (about 1.4\% compared to about $2.3 \%$ ). In a similar vein, a one-standard-deviation change in the unemployment share in the phase of life 31-40 reduced Earning Points by about 1.8\%, when unemployment occurred in the social policy period 1 till 1978 , and about $1.5 \%$ in the second social policy period after 1978. A one-standard-deviation change in the unemployment share in the phase of life 41-50 reduced Earning Points by about $2.9 \%$, when unemployment occurred in the social policy 
period $2(1979-1991)$ and by about $1.9 \%$ in the third social policy period after 1992 . In any event, inferences do not change overall.

\section{Conclusion}

The time at which an unemployment-induced employment-break occurs in a worker's career has had an influence on the pension benefits for West German men who retired in 2004. My results show that unemployment in between 31 and 50 reduced pension benefits (Earning Points) more severely than unemployment spells in the phases of life 21-30 and 51-60. Social security policy somewhat compensated for the penalties suffered due to unemployment. Social security policy compensation was especially high when unemployment occurred in the second policy period 1979-1991. The results should however be interpreted cautiously because the data used only covers individuals who retired in 2004.

The policy conclusions one may want to draw from my study are as follows. Advocates of policies which insure against any present and future income losses would claim that employment-breaks due to unemployment in the middle phases of life could be given more coverage. To be sure, such policies would have significant distributional effects. The German public pension system has been introduced as a Bismarckian system which is characterized by a close contribution-benefit linkage. ${ }^{18}$ Intragenerational redistribution via compensation for employment-breaks weakens the close contribution-benefit linkage. Intergenerational redistribution is especially offensive when social security policy privileges a particular cohort. ${ }^{19}$ Advocates of governments that provide incentive-compatible social policies would claim that employment-breaks due to unemployment in the middle phases of

\footnotetext{
${ }^{18}$ See Breyer and Hupfeld (2009) and (2010), and Breyer and Kifmann (2004), for example, for discussions of the contribution-benefit linkage in the German pension system.

${ }^{19}$ Fisher and Keuschnigg (2010), for example, illustrate how several pension reform scenarios are geared either towards young or old workers or both groups. See Colombino et al. (2011) on labor supply responses to pension reforms in Norway.
} 
life could be given less coverage. With less coverage individuals are more likely to (1) try harder not to be laid off and to (2) overcome periods of unemployment faster.

A further implication of my study is that theoretical approaches examing the influence of human capital accumulation on income should take into account the institutional set-up. Considering these institutions might also render macroeconomic labor market studies more relevant (e.g., Burdett et al. 2009). So far, the macroeconomic literature has not investigated the institutions and social security policies that affect human capital accumulation and income. 


\section{References}

Beblo, M., Bender, S., Wolf, E. (2009). Establishment-level wage effects of entering motherhood. Oxford Economic Papers 61: i11-i34.

Beblo, M., Wolf, E. (2002). Wage penalties for career interruptions - an empirical analysis for West Germany. ZEW Discussion Paper No. 02-45.

Becker, G.S. (1964). Human capital - a theoretical and empirical analysis, with special reference to education. Columbia University Press, New York and London.

Bieber, U., Stegmann, M. (2000). Sozialversicherungspflichtige Teilzeitbeschäftigung in den Erwerbsbiographien der zukünftigen Rentnerinnen und ihre Auswirkungen auf die Altersvorsorge. Deutsche Rentenversicherung 6: 364-383.

Börsch-Supan, A., Reil-Held, A., Schunk, D. (2008). Saving incentives, old-age provision and displacement effects: evidence from the recent German pension reform. Journal of Pension Economics and Finance 7: 295-319.

Breyer, F., Hupfeld, S. (2009). Fairness of public pensions and old-age poverty. FinanzArchiv 65: 358-380.

Breyer, F., Hupfeld, S. (2010). On the fairness of early-retirement provision. German Economic Review 11: 60-77.

Breyer, F., Kifmann, M. (2002). Incentives to retire later - a solution to the social security crises? Journal of Pension Economics and Finance 1: 111-130.

Breyer, F., Kifmann, M. (2004). The German retirement benefit formula: drawbacks and alternatives. FinanzArchiv 60. 63-82.

Bucheli, M., Forteza, A., Rossi, I. (2010). Work histories and the access to contributory pensions: the case of Uruguay.

Journal of Pension Economics and Finance 9: 369-391.

Burdett, K., Carillo-Tudela, C., Coles, M.G. (2009). Human capital accumulation and labour market equilibrium. IZA Discussion Paper No. 4215.

Coile, C.C., Levine, P.B. (2007). Labor market shocks and retirement: do government programs matter? Journal of Public Economics 91: 1902-1919.

Colombino, M., Hernæs, E., Locatelli, M. Strøm, S. (2011). Pension reforms, liquidity constraints and labour supply responses.

Journal of Pension Economics and Finance 10: 53-74.

Dreher, A., Gassebner, M. (2007). Greasing the wheels of entrepreneurship? The impact of regulations and corruption on firm entry. CESifo Working Paper No 2013. 
Fachinger, U., Himmelreicher, R.K. (2006). Die Bedeutung des Scientific Use Files Vollendete Versichertenleben 2004 (SUFVVL2004) aus der Perspektive der Ökonomik. Deutsche Rentenversicherung Heft 9-10: 562-582.

Fehr, H., Habermann, C. (2006). Pension reform and demographic uncertainty: the case of Germany. Journal of Pension Economics and Finance 5: 69-90.

Fehr, H., Kallweit, M., Kindermann, F. (2011). Pension reform with variable retirement age: a simulation analysis for Germany. Journal of Pension Economics and Finance, forthcoming.

Fisher, W.H., Keuschnigg, C. (2010). Pension reform and labor market incentives. Journal of Population Economics 23: 769-803.

Friedrich, R.J. (1982). In defence of multiplicative terms in multiple regression equations. American Journal of Political Science 26: 797-833

Frommert, D., Ohsmann, S., Rehfeld, U. (2008). Altervorsorge in Deutschland 2005 (AVID 2005). Die neue Studie im Überblick.

Deutsche Rentenversicherung Heft 1: 1-19.

Geyer, J., Steiner, V. (2007). Short-run and long-term effects of childbirth on mothers' employment and working hours across institutional regimes - an empirical analysis based on the European Community Household Panel. DIW Discussion Paper No. 682.

Geyer, J., Steiner, V. (2010). Public pensions, changing employment patterns, and the impact of pension reforms across birth cohorts - a microsimulation analysis for Germany. School of Business \& Economics Discussion Paper 2010/8. Free University Berlin.

Görlich, D., De Grip, A. (2009). Human capital depreciation during hometime. Oxford Economic Papers 61: i98-i121.

Hauschild, C. (2002). Empirische Haushaltsbiographietypen und ihre finanzielle Situation im Alter, Diskussionspapier Forschungsnetzwerk Alterssicherung der Deutschen Rentenversicherung.

Himmelreicher, R.K., Frommert, D. (2006). Gibt es Hinweise auf zunehmende Ungleichheit der Alterseinkünfte und zunehmende Altersarmut? Der Einfluss von Erwerbs- und Familienbiographien auf die Rentenhöhe in Deutschland. Vierteljahreshefte zur Wirtschaftsforschung 75: 108-130.

Hupfeld, S. (2009). Rich and healthy - better than poor and sick? An empirical analysis of income, health, and the duration of the pension benefit spell. Journal of Health Economics 28: 427-443. 
Hupfeld, S. (2011). Non-monotonicity in the longevity-income-relationship. Journal of Population Economics 24: 191-211.

Kortmann, K., Schatz, C. (1999). Zusammenfassung wichtiger Ergebnisse der Untersuchung 'Strukturen und Trends der Altersvorsorge von 40 - 60jährigen Rentenversicherten und ihrer Ehepartner', Deutsche Rentenversicherung Heft 10-11: 573-597.

Kunze, A. (2002). The timing of careers and human capital depreciation. IZA Discussion Paper No. 509.

Lachance, M.-E. (2011). Opitmal onset and exhaustion of retirement savings in a life-cycle model. Journal of Pension Economics and Finance, forthcoming.

Licht, G., Steiner, V. (1992). Individual income dynamics, human capital effects and non-employment spells. Jahrbücher für Nationalökonomie und Statistik 209/3-4: 241-265.

Light, A., Ureta, M. (1995). Early-career work experience and gender wage differentials. Journal of Labor Economics 13: 121-154.

Lühning, R. (2006). Entwicklung des Leistungsrechts der gesetzlichen Rentenversicherung der Bundesrepublik Deutschland seit der großen Rentenreform von 1957 (1957-2004). Logos Verlag, Berlin.

Mincer, J. (1974). Schooling, experience and earnings. Columbia University Press, New York.

Mincer, J. (1993). Studies in human capital - Collected essay of Jacob Mincer - Volume 1. Edward Elgar, Cambridge.

Mincer, J., Polachek, S. W. (1974). Family investments in human capital: earnings of Women. Journal of Political Economy 82: 76-108.

Mincer, J., Ofek, H. (1982). Interrupted work careers: Depreciation and restoration of human Capital. Journal of Human Resources 17: 3-24.

Roth, M. (2000). Zentrale Ergebnisse zur Altersvorsorge der Rentenversicherten der Geburtsjahrgänge 1936-1955. DRV-Schriften 23: 12-37.

Schatz, C., Merz, J., Kortmann, K. (2002). Künftige Alterseinkommen - eine Mikrosimulationsstudie zur Entwicklung der Renten und Altersvorsorge in Deutschland (AVID’96). Schmollers Jahrbuch 122: 227-260.

Stegmann, M. (2006a). Aufbereitung der Sondererhebung 'Vollendete Versichertenleben 2004' als Scientific Use File für das FDZ-RV'. Deutsche Rentenversicherung Heft 9-10: 537-553. 
Stegmann, M. (2006b). Die Bedeutung des Scientific Use Files FDZ-BiografiedatenVVL2004 (SUFVVL2004) für die Arbeitsmarktforschung'.

Deutsche Rentenversicherung Heft 9-10: 554-561.

Steiner, V. (2003). The protection of low-wage earners in old-age - an empirical reflection.

DRV-Schriften 43: 75-83.

Uysal, S.D., Pohlmeier, W. (2011). Unemployment duration and personality.

Journal of Economic Psychology, forthcoming.

Wunder, C. (2005). Arbeitslosigkeit und Alterssicherung - der Einfluss früherer

Arbeitslosigkeit auf die Höhe der gesetzlichen Altersrente.

Zeitschrift für Arbeitsmarktforschung 4: 493-509.

\section{Table 1}

Descriptive statistics on the sum of the Earning Points in relation to the period of coverage under the German pension insurance system .

\begin{tabular}{l|ccccc}
\hline $\begin{array}{c}\text { Period of } \\
\text { coverage in years }\end{array}$ & $\mathbf{N}$ & $\begin{array}{c}\text { Mean Earning } \\
\text { Points }\end{array}$ & $\begin{array}{c}\text { Period of coverage } \\
\text { in years } \\
\text { (intervals) }\end{array}$ & N (intervals) & $\begin{array}{c}\text { Mean Earning } \\
\text { Points } \\
\text { (intervals) }\end{array}$ \\
\hline Overall & 4723 & 52.13 & & & 16.96 \\
$>=\mathbf{2 0}$ & 4522 & 54.02 & $>=\mathbf{2 0} ;<=\mathbf{2 4}$ & 70 & 21.55 \\
$>=\mathbf{2 5}$ & 4445 & 54.66 & $>=\mathbf{2 5} ;<=\mathbf{2 9}$ & 68 & 29.58 \\
$>=\mathbf{3 0}$ & 4359 & 55.03 & $>=\mathbf{3 0} ;<=\mathbf{3 4}$ & 107 & 34.53 \\
$>=\mathbf{3 5}$ & 4225 & 56.11 & $>=\mathbf{3 5} ;<=\mathbf{3 9}$ & 171 & 49.17 \\
$>=\mathbf{4 0}$ & 4006 & 57.20 & $>=\mathbf{4 0} ;<=\mathbf{4 4}$ & 464 & 58.14 \\
$>=\mathbf{4 5}$ & 3306 & 58.47 & $>=\mathbf{4 5} ;<=\mathbf{4 9}$ & 2755 & \\
$>=\mathbf{5 0}$ & 179 & 62.01 & & & \\
\hline
\end{tabular}

Table 2

Distribution of the Earning Points and shares in relation to the (Un) employment phases.

\begin{tabular}{|c|c|c|c|c|}
\hline Employment Phase & & $N$ & $\begin{array}{l}\text { Mean Earning } \\
\text { Points }\end{array}$ & $\begin{array}{c}\text { Mean Share of Unemployment } \\
\text { (Share if } \neq 0)\end{array}$ \\
\hline \multirow{2}{*}{ Age $21-30$} & unemployed & 283 & 49.04 & 0.056 \\
\hline & employed & 4126 & 55.04 & 0 \\
\hline \multirow{2}{*}{ Age $31-40$} & unemployed & 594 & 46.68 & 0.088 \\
\hline & employed & 3851 & 55.89 & 0 \\
\hline \multirow{2}{*}{ Age $41-50$} & unemployed & 608 & 45.44 & 0.131 \\
\hline & employed & 3837 & 56.12 & 0 \\
\hline \multirow{2}{*}{ Age $51-60$} & unemployed & 997 & 51.61 & 0.210 \\
\hline & employed & 3448 & 55.54 & 0 \\
\hline \multirow{2}{*}{$\begin{array}{l}\text { Entire working } \\
\text { period }\end{array}$} & unemployed & 1741 & 50.62 & 0.051 \\
\hline & employed & 2704 & 57.26 & 0 \\
\hline
\end{tabular}


Table 3.

Descriptive Statistics. At least 25 years' coverage under the German pension insurance system.

\begin{tabular}{|c|c|c|c|c|c|}
\hline & Obs. & Mean & Std. Dev. & Min & Max \\
\hline Earning Points & 4445 & 54.66 & 14.23 & 5.8 & 87.8 \\
\hline Unemployment entire period & 4445 & 0.02 & 0.04 & 0 & 0.46 \\
\hline Unemployment (age 21-30) & 4445 & 0.00 & 0.02 & 0 & 0.41 \\
\hline Unemployment (age 31-40) & 4445 & 0.01 & 0.05 & 0 & 0.68 \\
\hline Unemployment (age 41-50) & 4445 & 0.02 & 0.07 & 0 & 0.94 \\
\hline $\begin{array}{l}\text { Unemployment (age 51-60) } \\
\text { Unemployment Policy Period } 1\end{array}$ & 4445 & 0.05 & 0.12 & 0 & 1 \\
\hline $\begin{array}{l}\text { (till 1978) } \\
\text { Unemployment Policy Period } 2\end{array}$ & 4445 & 0.14 & 0.35 & 0 & 1 \\
\hline $\begin{array}{l}\text { (1979-1991) } \\
\text { Unemployment Policy Period } 3 \text { (since }\end{array}$ & 4445 & 0.18 & 0.38 & 0 & 1 \\
\hline 1992) & 4445 & 0.23 & 0.42 & 0 & 1 \\
\hline Family Status (Married) & 4445 & 0.85 & 0.36 & 0 & 1 \\
\hline Citizenship (German) & 4445 & 0.97 & 0.18 & 0 & 1 \\
\hline Lower school (Hauptschule) & 4445 & 0.10 & 0.29 & 0 & 1 \\
\hline Secondary School (Realschule) & 4445 & 0.60 & 0.49 & 0 & 1 \\
\hline $\begin{array}{l}\text { High School Diploma (Abitur) with } \\
\text { professional training } \\
\text { High School Diploma (Abitur) without } \\
\text { professional training }\end{array}$ & $\begin{array}{l}4445 \\
4445\end{array}$ & 0.00 & 0.07 & 0 & 1 \\
\hline Advanced Technical College Degree & 4445 & 0.06 & 0.25 & 0 & 1 \\
\hline University Degree & 4445 & 0.05 & 0.23 & 0 & 1 \\
\hline Education unknown & 4445 & 0.17 & 0.38 & 0 & 1 \\
\hline
\end{tabular}




\section{Table 4}

Regression Results. OLS, robust standard errors. At least 25 years' coverage under the German pension insurance system.

Dependent variable: log Earning Points.

Only unemployment shares included.

(1)

$-0.0865^{* * *}$

[16.81]

Unemployment (age 21-30)

Unemployment (age 31-40)

Unemployment (age 41-50)

Unemployment (age 51-60)

Family Status (Married)

Citizenship (German)

Lower school (Hauptschule)

Secondary School (Realschule)

High School Diploma (Abitur) with professional training

High School Diploma (Abitur) without professional training

Advanced Technical College Degree

University Degree

\begin{tabular}{lcccc} 
Constant & $3.9575^{* * *}$ & $3.9575^{* * *}$ & $3.4977^{* * *}$ & $3.5027^{* * *}$ \\
& {$[856.72]$} & {$[862.78]$} & {$[113.60]$} & {$[113.99]$} \\
\hline Observations & 4445 & 4445 & 4445 & 4445 \\
R-squared & 0.07 & 0.09 & 0.21 & 0.22 \\
\hline
\end{tabular}

(2)

(3)

(4) $-0.0673 * * *$

[13.38]

$$
\begin{gathered}
-0.0076^{*} \\
{[1.74]} \\
-0.0416^{* * *} \\
{[7.34]} \\
-0.0576^{* * *} \\
{[10.00]} \\
-0.0270^{* * *} \\
{[4.95]}
\end{gathered}
$$$$
-0.0075^{*}
$$$$
\text { [1.87] }
$$$$
-0.0358 * * *
$$$$
\text { [6.74] }
$$$$
-0.0455 * * *
$$

$0.1291^{* * *}$ $0.1253^{* * *}$

[10.29] $0.2340 * * * \quad 0.2280^{* * *}$

[8.87]

$-0.0430 * *$ $-0.0355^{*}$

[2.17]

$0.1523^{* * *}$ $0.1571^{* * *}$

[10.20]

[10.58]

$0.1608 * * *$

$0.1628^{* * *}$

[3.79]

[3.81]

$0.1929^{* * *} \quad 0.2041^{* * *}$

[2.86]

$0.3219 * * * \quad 0.3240 * * *$

[18.44]

[18.64]

$0.2491 * * * \quad 0.2515^{* * *}$

[12.57]

[12.67]

t-statistics in parentheses: $* * * / * * *$ : significant at the $0.10 / 0.05 / 0.01$ level. 


\section{Table 5}

Regression Results. OLS, robust standard errors. At least 25 years' coverage under the German pension insurance system.

Dependent variable: log Earning Points.

Unemployment shares, policy period dummies and interaction terms included.

(1)

\begin{tabular}{|c|c|c|}
\hline & & \\
\hline Unemployment (age 21-30) & $\begin{array}{c}-0.0012 \\
{[0.26]}\end{array}$ & $\begin{array}{l}-0.003 \\
{[0.72]}\end{array}$ \\
\hline Unemployment (age 31-40) & $\begin{array}{c}-0.0424 * * * \\
{[3.08]}\end{array}$ & $\begin{array}{c}-0.0414^{* * *} \\
{[3.28]}\end{array}$ \\
\hline Unemployment (age 41-50) & $\begin{array}{c}-0.0352 * * * \\
{[5.96]}\end{array}$ & $\begin{array}{c}-0.0301 * * * \\
{[5.28]}\end{array}$ \\
\hline Unemployment (age 51-60) & $\begin{array}{c}-0.0314 * * * \\
{[4.03]}\end{array}$ & $\begin{array}{c}-0.0207 * * * \\
{[2.81]}\end{array}$ \\
\hline Unemployment Policy Period 1 (till 1978) & $\begin{array}{c}-0.0178^{* * *} \\
\quad[2.97]\end{array}$ & $\begin{array}{c}-0.0120^{* *} \\
{[2.17]}\end{array}$ \\
\hline Unemployment Policy Period 2 (1979-1991) & $\begin{array}{c}-0.0560 * * * \\
{[10.04]}\end{array}$ & $\begin{array}{c}-0.0423^{* * *} \\
{[7.98]}\end{array}$ \\
\hline $\begin{array}{l}\text { Unemployment Policy Period } 3 \text { (since } 1992 \text { ) } \\
\text { Unemployment (age } 31-40)^{*}\end{array}$ & $\begin{array}{l}0.0100 \\
{[1.40]}\end{array}$ & $\begin{array}{l}0.0063 \\
{[0.95]}\end{array}$ \\
\hline $\begin{array}{l}\text { Unemployment Policy Period } 2 \text { (1979-1991) } \\
\text { Unemployment (age 41-50)* }\end{array}$ & $\begin{array}{c}0.0122^{*} \\
{[1.90]}\end{array}$ & $\begin{array}{c}0.0117^{* *} \\
\quad[1.97]\end{array}$ \\
\hline Unemployment Policy Period 3 (since 1992) & $\begin{array}{l}0.0007 \\
{[0.18]}\end{array}$ & $\begin{array}{r}0.0017 \\
{[0.47]}\end{array}$ \\
\hline Family Status (Married) & & $\begin{array}{c}0.1211 * * * \\
{[9.79]}\end{array}$ \\
\hline Citizenship (German) & & $\begin{array}{c}0.2227 * * * \\
{[8.56]}\end{array}$ \\
\hline Lower school (Hauptschule) & & $\begin{array}{c}-0.0424 * * \\
{[2.15]}\end{array}$ \\
\hline Secondary School (Realschule) & & $\begin{array}{c}0.1484 * * * \\
{[9.94]}\end{array}$ \\
\hline $\begin{array}{l}\text { High School Diploma (Abitur) with } \\
\text { professional training }\end{array}$ & & $\begin{array}{c}0.1498^{* * *} \\
{[3.48]}\end{array}$ \\
\hline $\begin{array}{l}\text { High School Diploma (Abitur) without } \\
\text { professional training }\end{array}$ & & $\begin{array}{c}0.1998^{* * *} \\
{[3.25]}\end{array}$ \\
\hline Advanced Technical College Degree & & $\begin{array}{c}0.3069 * * * \\
{[17.34]}\end{array}$ \\
\hline University Degree & & $\begin{array}{c}0.2358 * * * \\
{[11.76]}\end{array}$ \\
\hline Constant & $\begin{array}{c}3.9526^{* * *} \\
{[738.27]} \\
\end{array}$ & $\begin{array}{c}3.5144 * * * \\
{[114.63]} \\
\end{array}$ \\
\hline Observations & 4445 & 4445 \\
\hline R-squared & 0.11 & 0.24 \\
\hline
\end{tabular}


Table 6

Marginal Effects.

\begin{tabular}{cccc}
\hline & & (1) & (2) \\
\hline & Unemployed in Policy Period 1 & $-0.048^{* * *}$ & $-0.047 * * *$ \\
Unemployment (age 31-40) & (till 1978) & {$[2.92]$} & {$[3.09]$} \\
& Unemployed in Policy Period 2 & $-0.016^{* *}$ & $-0.016^{* * *}$ \\
& (till 1979-1991) & {$[2.58]$} & {$[2.73]$} \\
\hline & Unemployed in Policy Period 2 & $-0.036^{* * *}$ & $-0.031^{* * *}$ \\
Unemployment (age 41-50) & (till 1979-1991) & {$[5.19]$} & {$[4.76]$} \\
& Unemployed in Policy Period 3 & $-0.034 * * *$ & $-0.027 * * *$ \\
& (since 1992) & {$[4.36]$} & {$[3.71]$} \\
\hline
\end{tabular}

